\title{
Editorial
}

\section{CNBC Institutional Investor Delivering Alpha Conference in New York, 15 July 2015}

Journal of Asset Management (2015) 16, 363-364. doi:10.1057/jam.2015.27

On 15 July Delivering Alpha once again impressed everyone by its lineup of top hedge fund managers, well-known money managers and CEOs. On stage we saw billionaire activist investor Carl Icahn, his third consecutive year at the conference and Larry Fink CEO of Blackrock, the largest index provider in the world. What happened next was totally unexpected; Icahn attacked Fink and stressed how hazardous index funds were. Icahn claimed the only thing Blackrock sold was liquidity, but in fact Icahn stressed that Blackrock's funds were illiquid. Icahn compared Blackrock clients to a bus filled with index investors who were partying while Fink along with Janet Yellen were pushing the bus, which was coming closer to the end of the cliff. Icahn emphasized several times that Blackrock was a 'dangerous company' and would 'blow-up' because of illiquidity, however, Fink denied all this and even suggested that the Fed would not raise rates in September. Perhaps Icahn is shorting Blackrock?

Next CEO Bill Ackman of Pershing Square Management believed that Fannie Mae and Freddie Mac had more upside than downside and Ackman was holding positions in both firms. Activist investor Nelson Peltz of Trian Fund Management reiterated that as an activist he is a long-term owner of Wendy's and Heinz while defending the criticism that activist investors are not shortterm traders that only 'maximize shareholder wealth for investors without regarding the fundamental growth of their targets for investors is wrong'. Peltz mentioned his two new positions made up 33 per cent of his portfolio but was not ready to disclose them, however he hinted at one.

The Starboard Value CEO and CIO Jeffrey Smith signaled that shares of Macy's were undervalued and implied the shares would likely double to more than US $\$ 125$ per share. By the closing of the trading day on 15 July shares climbed nearly 8 per cent on this news. In addition, Mr Smith did not reveal the number of shares his fund had in Macy's. On the same panel Tom Sandell of Sandell Asset Management advocated that Ethan Allen, a furniture company, now trading at lower levels is a good buy. On the news, shares spiked 4 per cent after his speech while emphasizing that Allen's real estate holdings coupled with its brand name would be undervalued and poised for an upturn but did not discuss his stake in the firm.

Ex-right-hand man of Carl Icahn, Keith Meister of Corvex Management revealed an 8 per cent position in American Realty Capital Properties. With this news the stock price ascended almost 3 per cent during the day and Meister believes there could be a move upwards in the 25-50 per cent range. Ms Leda Braga of Systematica reflected about the hot topic of humans versus machines and highlighted that 'algorithms cannot replace activists because of the human touch they bring to investments'. As the top female hedge fund manager she said that using data in 
a controlled fashion has created a loyal following with almost $\$ 9$ billion under management.

Jonathan Gray, global head of real estate at The Blackstone Group suggested that China is 'leading the boom in real estate with a great deal of foreign capital coming from Canada, Europe, the Middle East' and Far East. In addition, he believes the market has not reached a peak, recapping that it is different 'this time around when compared to 2008. $\mathrm{He}$ also is bullish on Brazil, China and other countries in Europe'.

Gregory Beard who is the head of natural resources at Apollo Global Management believes that 'global oil demand may not peak for 10 to 15 years' since nobody has found a worldwide substitute for oil, prices will likely stay at current prices. Beau Taylor, Founding Partner and Chief Investment Officer, Taylor Woods Capital Management LLC, noted 'it will be hard for oil to rally' and added that 'oil currently sits in a supply-led bear market and further downside seems more likely than prices rising, with the bar to a selloff being relatively low'.

The crisis in Greece suggests that there are a great deal of bargains in Europe as Mary Callahan Erdoes, CEO of J.P. Morgan Asset Management announced and stressed that Europe should be concerned with areas such as the 'conflicts in the Ukraine and Russia' as also confirmed by Richard Perry, CEO of Perry Capital Partners. Christopher Ailman, CIO of the California State Teachers' Retirement System is 'heavily weighted in the US and hinted that China and other Asian countries could possibly be large additions to his portfolio'. On the flip side Paul Singer President of Elliot Management suggested that China is a 'wild bull market' with government interference fueling the boom. $\mathrm{He}$ finds it difficult to evaluate Asian markets and cites an example of the Shanghai composite index 'surging more than 80 per cent in 2014 a result of governmental manipulation of Chinese markets'. Investors do not believe the exaggerated prices of many stocks but he mentioned it will likely not cause a global meltdown.

Founder Jeffrey Gundlach of Doubline Capital suggested he will 'remove his short position on Chipotle since the company is back on track, set to grow and will do the same for Delta Air Lines'. In addition he also did not see a 'liquidity problem in bonds' and maintained his stance that the Fed would not increase rates in 2015. Bill Miller, Chairman and Chief Investment Officer, LMM LLC recommended as a result of Twitter's drop it is a strong buy at this stage. Esther Dyson, Head of EDventure Holdings and co-panelist Scott Kupor, Managing Partner and COO at Andreessen Horowitz, advocated some concerns about the technology sector and the possibility that Nasdaq is in a bubble; however, not like 2000 since 'all the growth in the stocks has been earnings driven and not $\mathrm{P} / \mathrm{E}$ driven'.

Delivering Alpha once again produced a stellar group of money managers and CEOs and the conference was very successful attracting many new investors as well as returning investors to a full house year after year. This conference is a must for pension fund managers, insurance companies, institutional investors, hedge fund managers, money managers and family offices.

Greg N. Gregoriou, PhD Derivatives Editor, Professor of Finance at SUNY Plattsburgh, State University of New York (Plattsburgh), Plattsburgh, USA E-mail: gregorg@plattsburgh.edu 